\section{Seasonal Patterns of Photosynthesis and Stomatal Conductance in Lowbush Blueberry Plants Managed in a Two- year Production Cycle}

\author{
Peter R. Hicklenton and Julia Y. Reekie \\ Agriculture and Agri-Food Canada, Atlantic Food and Horticulture Research \\ Centre, Kentville, N.S., Canada B4N 1J5
}

\author{
Robert J. Gordon \\ Nova Scotia Department of Agriculture and Marketing, P.O. Box 550, Truro, \\ N.S., Canada B2N $5 E 3$
}

\author{
David C. Percival \\ Department of Environmental Sciences, Nova Scotia Agricultural College, \\ P.O. Box 550, Truro, N.S., Canada B2N 5E3
}

Additional index words. $\mathrm{CO}_{2}$ assimilation, light response, leaf water potential, soil moisture, fruiting, pruning, Vaccinium angustifolium

\begin{abstract}
Seasonal patterns of $\mathbf{C O}_{2}$ assimilation $\left(\mathbf{A}_{\mathrm{CO} 2}\right)$, leaf water potential $\left(\psi_{1}\right)$ and stomatal conductance $\left(\mathrm{g}_{1}\right)$ were studied in three clones ('Augusta', 'Brunswick', and 'Chignecto') of lowbush blueberry (Vaccinium angustifolium Ait.) over two growing seasons. Plants were managed in a 2-year cycle of fruiting (year 1) and burn-prune (year 2). In the fruiting year, $\mathrm{A}_{\mathrm{CO} 2}$ was lowest in mid-June and early September. Rates peaked between 10 and 31 July and declined after fruit removal in late August. Compared with the fruiting year, $A_{\mathrm{CO}_{2}}$ in the prune year was between $50 \%$ and $130 \%$ higher in the early season, and between $80 \%$ and $300 \%$ higher in mid-September. In both years, however, mid-season maximum $A_{\mathrm{CO} 2}$ for each clone was between 9 and $10 \mu \mathrm{mol} \cdot \mathrm{m}^{-2} \cdot \mathrm{s}^{-1} \mathrm{CO}_{2}$. Assimilation of $\mathrm{CO}_{2}$ increased with increasing photosynthetic photon flux $(P P F)$ to between 500 and $600 \mu \mathrm{mol} \cdot \mathrm{s}^{-1} \cdot \mathrm{m}^{-2}$ in 'Augusta' and 'Brunswick', and to between 700 and $800 \mu \mathrm{mol} \cdot \mathrm{s}^{-1} \cdot \mathrm{m}^{-2}$ in 'Chignecto'. Midday $\psi_{1}$ was generally lower in the prune year than in the fruiting year, reflecting year-to-year differences in soil water content. Stomatal conductance $\left(\mathrm{g}_{1}\right)$, however, was generally higher in the prune year than in the fruiting year over similar vapor pressure deficit (VPD) ranges, especially in June and September when prune year $g_{1}$ was often twice that observed in the fruiting year. In the fruiting year, $g_{1}$ declined through the day in response to increasing VPD in June, but was quite constant in mid-season. It tended to be higher in 'Augusta' than in the other two clones. Stomatal closure imposes limitations on $\mathrm{A}_{\mathrm{CO} 2}$ in lowbush blueberries, but not all seasonal change in $\mathrm{C}$-assimilative capacity can be explained by changes in $\mathrm{g}_{1}$.
\end{abstract}

The wild lowbush blueberry is farmed on $>26,000$ ha in Maine and the Canadian Maritime Provinces. Total berry production in 1997 exceeded 137 million pounds with a crop value of about U.S. $\$ 45$ million. The crop is typically managed in a biennial production system in which plants are mowed or burned in alternate years to force regrowth of fruiting shoots (Ismail and Hanson, 1982). Plants grow vegetatively for 1 year following pruning. Flower buds are formed toward the end of the year; flowering and pollination occur during

Received for publication 25 Jan. 1999. Accepted for publication 16 June 1999. Research supported in part by grants from the Nova Scotia Wild Blueberry Institute and the Matching Investment Initiative Program of Agriculture and Agri-Food Canada. Contribution no. 2196, Atlantic Food and Horticulture Research Centre. The cost of publishing this paper was defrayed in part by the payment of page charges. Under postal regulations, this paper therefore must be hereby marked advertisement solely to indicate this fact. the following spring, and the crop is harvested in July and August.

Despite the importance of the crop, very little is known of its ecophysiology. This has hampered both our understanding of the environmental limitations to productivity and attempts to improve production through changes in crop management. The effect of environment on $\mathrm{CO}_{2}$ assimilation has been extensively studied in many small fruit crops (Fernandez and Pritts, 1994; Moon et al., 1987; Percival et al., 1996) but has received very little attention in lowbush blueberry. Study of environmental physiology in lowbush blueberry is complicated by the genetic heterogeneity among plants. Commercial blueberry fields, generally developed on abandoned pasture or cleared woodland, consist of a mixed, wild population of seedlings. Seedlings spread vegetatively by rhizomes (Trevett, 1956) to create large clumps that can be identified in the field as individual clones (Kender and Eggert, 1966). The clones may differ considerably in form (Vander Kloet, 1978), fruiting potential (Sanderson and Cutcliffe, 1991) and physiology (Forsyth and Hall, 1965), but there has thus far been no attempt to identify baseline information on physiological responses of lowbush blueberries under field conditions.

The present study was conducted using three lowbush blueberry clones to investigate: 1) the light saturation ranges for photosynthesis in the field; and 2) the seasonal variation in net $\mathrm{CO}_{2}$ assimilation and stomatal conductance over the course of two growing seasons ("fruiting" year and "prune" year), with an overall aim of improving our knowledge of fundamental factors governing assimilative capacity.

\section{Materials and Methods}

Plant material and location. Three 15-year old clones of lowbush blueberry growing at the Agriculture and Agri-Food Canada Experimental Farm, Sheffield Mills, N.S. $\left(45^{\circ} \mathrm{N}\right.$, $64.5^{\circ} \mathrm{W}$ ) were chosen for study. 'Augusta' and 'Chignecto' are characterized by a branched, low-mounding, growth form and small leaves, $\approx 3.3 \mathrm{~cm}$ long $\times 1.7 \mathrm{~cm}$ wide (Aalders et al., 1975; Hall et al., 1977); 'Brunswick' has a more vertical growth habit and larger leaves, $4.3 \mathrm{~cm} \times 1.7 \mathrm{~cm}$ (Aalders et al., 1977). The clones were growing in a well-drained loamysand soil of the Cornwallis series (Cann et al., 1954) and had been managed in a biennial system with burn-pruning for 14 years before the study began. Experiments were conducted over a 2-year (1996 and 1997) period and began with plants in the fruiting year.

Environmental measurements. Air temperature and relative humidity (RH) were measured continuously through each season using a model CS500 combined temperature/ Vaisala RH sensor (Campbell Scientific, Logan, Utah) in association with a model CR10 datalogger. The sensors were scanned every minute and readings were averaged each hour. Growing degree-days (GDD; $10{ }^{\circ} \mathrm{C}$ base) and VPD were calculated from the measurements. Volumetric soil water content was monitored using the time domain reflectometry (TDR) technique (Topp et al., 1980). Measurements were made each hour using 30-cm TDR sensors (Campbell Scientific Model CS615-L) inserted at an angle under blueberry plants to provide average volumetric soil water content for the top $15 \mathrm{~cm}$ of the soil profile. Equipment failure resulted in loss of soil water content data between 24 June and 18 July 1996.

Photosynthesis, stomatal conductance, and leaf water potential measurements. Photosynthesis was measured on nine dates between 12 June and 19 Sept. 1996 and on eight dates between 19 June and 15 Sept. 1997. Earlier measurements in 1997 were not possible due to the slower leaf expansion in prune-year plants. Field measurements of $\mathrm{CO}_{2}$ uptake were estimated using an open-flow gas-exchange system consisting of a portable infrared gas analyzer (LCA-2; ADC Ltd., Hoddesdon, U.K.) and a temperature-controlled leaf chamber (PLC2A). Measurements of chamber flow rate, $\mathrm{CO}_{2}$ exchange, leaf and 
air temperature, and chamber RH were recorded and used to calculate net photosynthesis (von Caemmerer and Farquhar, 1981). All measurements were conducted between 1000 and $1500 \mathrm{HR}$ on leaves which had reached $>80 \%$ full lamina expansion. Chamber air temperature was maintained between 24 and $28^{\circ} \mathrm{C}$ and, except for the light response determinations, photosynthetic photon flux (PPF) incident on the chamber was always between 900 and $2000 \mu \mathrm{mol} \cdot \mathrm{s}^{-1} \cdot \mathrm{m}^{-2}$. The ambient atmospheric $\mathrm{CO}_{2}$ concentration was between 340 and $350 \mu \mathrm{L} \cdot \mathrm{L}^{-1}$. Light response curves were constructed from data obtained by placing neutral density filters directly over the chamber to progressively reduce the $P P F$. These data were collected on several dates between 10 and 31 July on fruiting-year plants only.

Stomatal conductance $\left(\mathrm{g}_{1}\right)$ was measured with a LI-1600 steady state porometer (LICOR Inc., Lincoln, Nebr.) according to standard protocols (McDermitt, 1990). Measurements were made in full sun between 0800 and $1700 \mathrm{HR}$ on the abaxial surface of leaves adjacent to those used for measuring photosynthesis.

Leaf water potential $\left(\psi_{1}\right)$ was measured using a pressure chamber (PMS Instrument Co. Ltd., Corvallis, Ore.) at the same time as $\mathrm{g}_{1}$. Leaves with a short length of attached stem tissue were removed from the upper canopy, placed immediately in a plastic bag, and inserted into the pressure chamber with the stem tip protruding through a rubber stopper. The chamber was pressurized with nitrogen at a rate not exceeding $0.03 \mathrm{MPa} \cdot \mathrm{s}^{-1}$ and the endpoint (when sap just returns to the cut surface of the xylem) was recorded.

Experimental design and data analysis. Measurements were conducted on five plants of each clone arranged in a randomized complete block. Three leaves were measured on each plant on each date to determine the seasonal pattern of $\mathrm{CO}_{2}$ assimilation. Seasonal response curves were fitted by least squares polynomial regression. Light response curves were constructed from measurements on a minimum of seven leaves per plant. Curves were fitted by nonlinear regression using an asymptotic function:

$$
\mathrm{Y}=\mathrm{B}(1) *[1-\mathrm{B}(2)] * \mathrm{e}^{[-\mathrm{B}(3) * \mathrm{X}]}
$$

and the Marquardt compromise method of successive approximations. The $\mathrm{g}_{1}$ was measured on one tagged leaf from each replicate plant throughout each measurement day. A new leaf was selected whenever a leaf was damaged or showed signs of cuvette-induced stomatal closure, and at the start of each day.

The $\psi_{1}$ was measured on successive single samples from each replicate plant. Analysis of $\psi_{1}$ data revealed no significant differences between clones at any single measurement time, so these data were pooled for presentation.

\section{Results and Discussion}

Light saturation of $\mathrm{A}_{\mathrm{CO} 2}$ occurred between 500 and $600 \mu \mathrm{mol} \cdot \mathrm{s}^{-1} \cdot \mathrm{m}^{-2}$ for 'Augusta' and

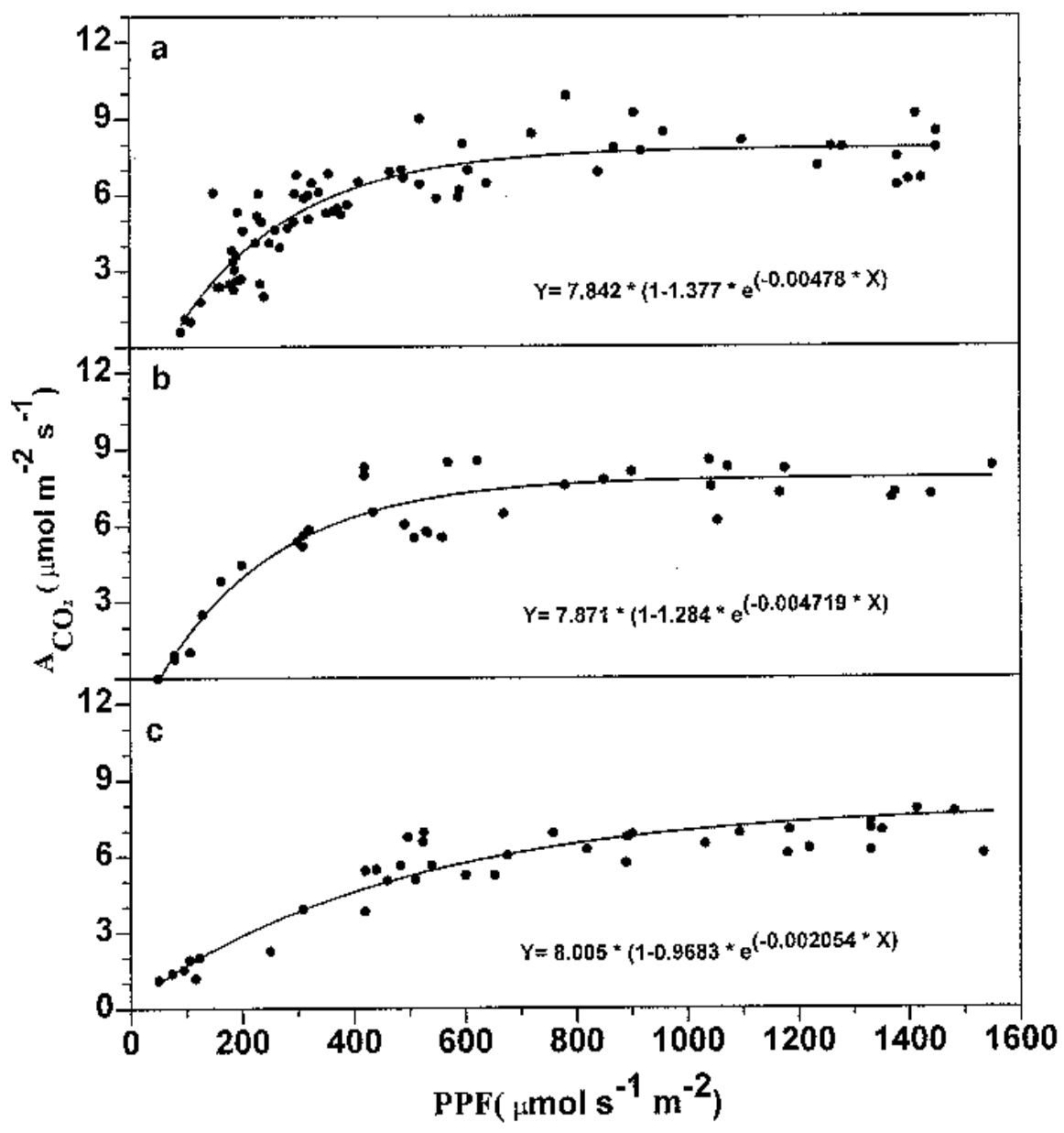

Fig. 1. The response of (a) 'Augusta', (b) 'Brunswick', and (c) 'Chignecto' lowbush blueberry to photosynthetic photon flux $(P P F)$. Measurements were made at 24 to $28^{\circ} \mathrm{C}$. Points are derived from measurement on at least seven leaves of five individual plants.

'Brunswick' clones (Fig. 1 a and b). For 'Chignecto' (Fig. 1c) the range was higher (between 700 and $800 \mu \mathrm{mol} \cdot \mathrm{s}^{-1} \cdot \mathrm{m}^{-2}$ ) although the $\mathrm{A}_{\mathrm{CO} 2} / P P F$ curve failed to reach a clear asymptote. Light saturation was between three and four times as high as previously inferred from laboratory studies (Forsyth and Hall, 1965). Both 'Augusta' and 'Brunswick' showed lower light saturation than highbush (V. corymbosum L.) (Moon et al., 1987), and rabbiteye (V.ashei Reade) blueberry (Teramura et al., 1979). The response of 'Chignecto', however, was similar to that of those other species. Vaccinium angustifolium has been classified as a shade-tolerant plant and is frequently found in heavily shaded, forest floor habitats (Hall, 1955). However, much higher light intensities are required to realize maximum growth and fruiting potential (Hall, 1958, Hall and Ludwig, 1961) and it is clear from the present data that, even under full-sun conditions, whole-plant $\mathrm{A}_{\mathrm{CO} 2}$ is unlikely to be saturated, given the often dense and interleaved branch structure.

For both fruiting and prune years, leaf $\mathrm{A}_{\mathrm{CO} 2}$ varied through the season (Fig. 2). Maximum rates for all clones were similar in both years, averaging between 9 and $10 \mu \mathrm{mol} \cdot \mathrm{m}^{-2} \cdot \mathrm{s}^{-1} \mathrm{CO}_{2}$, $\approx 20 \%$ lower than those reported for cultivars of the highbush blueberry (Moon et al., 1987) but $40 \%$ higher than those for rabbiteye blueberry (Teramura et al., 1979). Early season $\mathrm{A}_{\mathrm{CO} 2}$ (on 19 June) was lower in the fruiting year than in the prune year despite a $15 \%$ greater GDD accumulation to that date. Epicormic shoots arise vigorously from latent buds in below-ground crowns and rhizomes following pruning, and our data suggest that the early photosynthetic potential is greater in these shoots than in those that have overwintered above ground. Similar effects have been described in new shoots formed following grazing in grasses where $\mathrm{A}_{\mathrm{CO} 2}$ may be as much as $39 \%$ higher than in nongrazed plants (Dyer et al., 1991). The higher rates may be due to enhanced sink strength in the new shoots, since apical meristems are stronger sinks than existing shoot tissues and adventitious buds of some species (Chapman et al., 1991), although developing flower buds in fruiting-year plants are probably also strong sinks. $\mathrm{A}_{\mathrm{CO} 2}$ peaked in the fruiting year between 10 July and 31 July 1996 but there were some differences among clones (Fig. 2). 'Brunswick' showed highest rates on 31 July, when both 'Augusta' and 'Chignecto' had declined from their 10 July peak. In the prune year there was a closer similarity among the clones. Peak $\mathrm{A}_{\mathrm{CO} 2}$ occurred over a broader time period (from midJuly until mid-August), and higher GDD range, 
compared with the fruiting year. There were no differences in the maximum $\mathrm{A}_{\mathrm{CO} 2}$ among clones in either year. By 4 Sept. in the fruiting year, rates had declined to levels equivalent to those in early June, except in 'Augusta' in which higher rates were sustained through 18 Sept. The late season decline occurred after the fruit was removed from the plants in late August and resembled similar seasonal patterns following fruit removal in cherry (Prunus avium L.) (Gucci et al., 1991a), plum (Prunus domestica L.) (Gucci et al., 1991b), and peach (Prunus persica L.) (Mandre et al., 1995). In prune year plants there was no equivalent decline, and by mid-September, shortly before leaf senescence, $\mathrm{A}_{\mathrm{CO} 2}$ remained $\approx 65 \%$ of that in early August. The strong late season assimilative capacity in prune-year plants may reflect the sink strength of developing fruit and vegetative buds, roots, and rhizomes, which continue growth late into the fall (Kender and Abdalla, 1966). Similar sinks are present in fruiting-year plants, but fruit harvest represents the loss of a major sink, which may lead to a reduction in $\mathrm{A}_{\mathrm{CO} 2}$. Still, some reduction in $\mathrm{A}_{\mathrm{CO} 2}$ occurred in fruiting-year plants before fruit harvest, suggesting that factors other than fruit sink strength may also play a role in late season decline in $\mathrm{A}_{\mathrm{CO} 2}$. From a practical standpoint, the low assimilative capacity in September suggests that growers can prune plants after harvest with relatively little loss of potential C gain.

Throughout much of the season, volumetric soil moisture content was lower in the prune year as compared with the fruiting year, reflecting the much lower June to September precipitation in 1997 (Fig. 3). Excluding September, the study site received just $132 \mathrm{~mm}$ of rain in 1997, but $232 \mathrm{~mm}$ in the 1996 fruiting year, compared with a 35-year average of 237 $\mathrm{mm}$. The lower soil moisture levels were reflected in reduced daytime $\psi_{1}$ from late June until early September in prune-year plants (Fig. 4). For similar dates, in July and August, midday $\psi_{1}$ was between $20 \%$ and $60 \%$ lower in plants sampled in the prune year as compared with the fruiting year. Only for plants sampled in mid-June and mid-September were $\psi_{1}$ values similar throughout much of the day.

Diurnal $\mathrm{g}_{1}$ patterns changed through the season in both prune-year and fruiting-year plants. In the fruiting year, early season (19 and 26 June) $\mathrm{g}_{1}$ in each clone declined over the day (Fig. 5). On 19 June the decline mirrored the increase in VPD from $0.2 \mathrm{KPa}$ at $0800 \mathrm{HR}$ to $2.0 \mathrm{KPa}$ at $1700 \mathrm{HR}$, but on 26 June the decline occurred despite a relatively low and constant VPD. In highbush blueberries, declines in $\mathrm{g}_{1}$ of between 0.1 and $0.2 \mathrm{~mol} \cdot \mathrm{m}^{-2} \cdot \mathrm{s}^{-1}$ were associated with a decline in $\mathrm{A}_{\mathrm{CO} 2}$ of $\approx 20 \%$ (Moon et al., 1987). Similar declines in $g_{1}$ observed on 19 and 26 June in the present study may have contributed to the rather low values for $\mathrm{A}_{\mathrm{CO} 2}$ recorded on these dates in each clone. On mid-season sampling dates (10 and 31 July), $g_{1}$ was quite constant despite daytime increases in VPD of 0.6 and $1.3 \mathrm{KPa}$, respectively. On 4 Sept., early morning $\mathrm{g}_{1}$ in each clone had declined by between $11 \%$ ('Augusta') and 39\% ('Chignecto' and 'Brunswick')

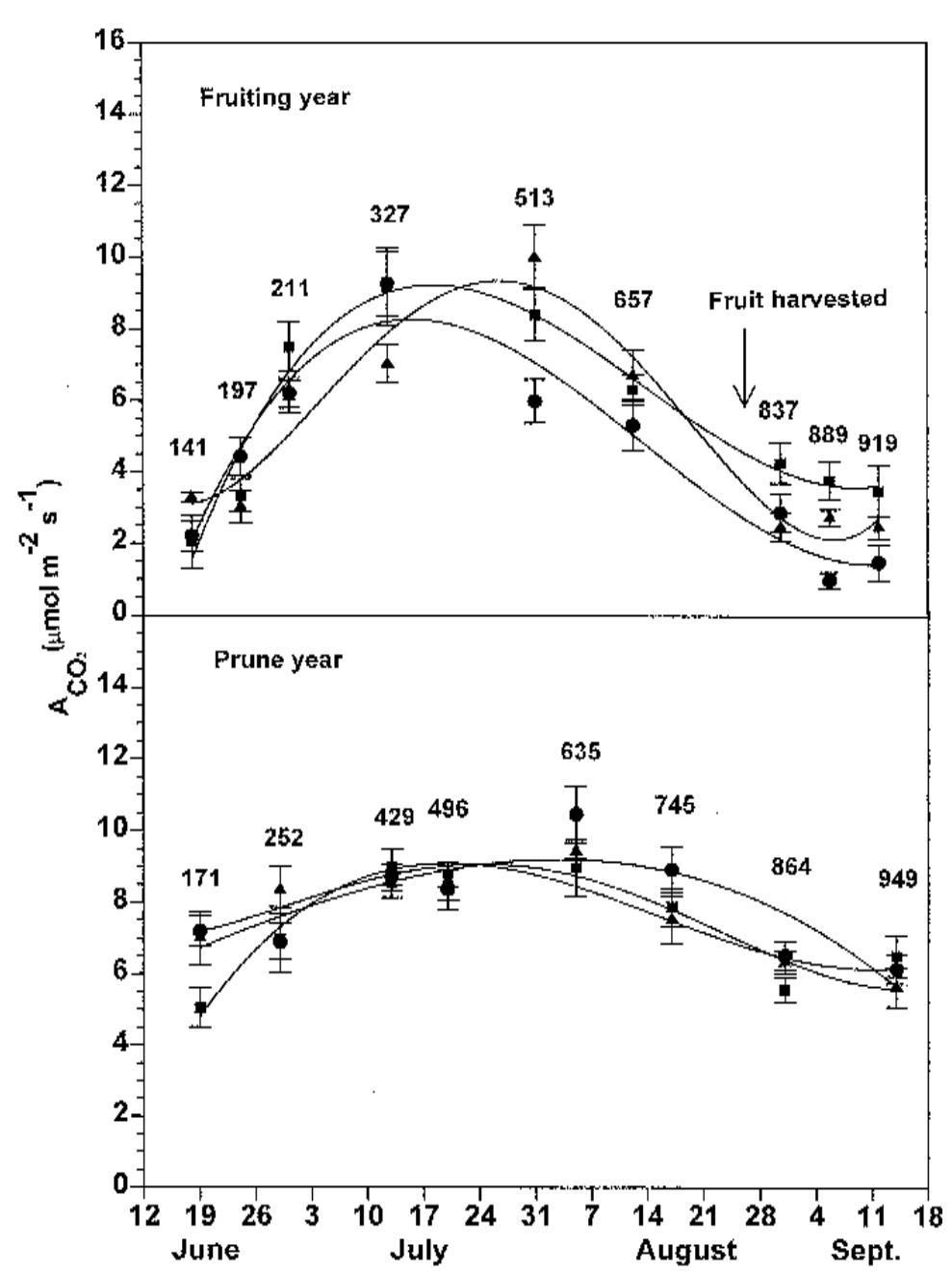

Fig. 2. Seasonal response of net $\mathrm{CO}_{2}$ assimilation in $(\mathbf{\square})$ 'Augusta', $(\mathbf{\Delta})$ 'Brunswick', and (-) 'Chignecto' lowbush blueberry for the fruiting year (1996) and in the prune year (1997). Numbers above each set of points indicate accumulated degree-days $\left(10^{\circ} \mathrm{C}\right.$ base $)$. Each point is the mean of three determination on each of five replicate plants. Bars indicate \pm 1 sEM.

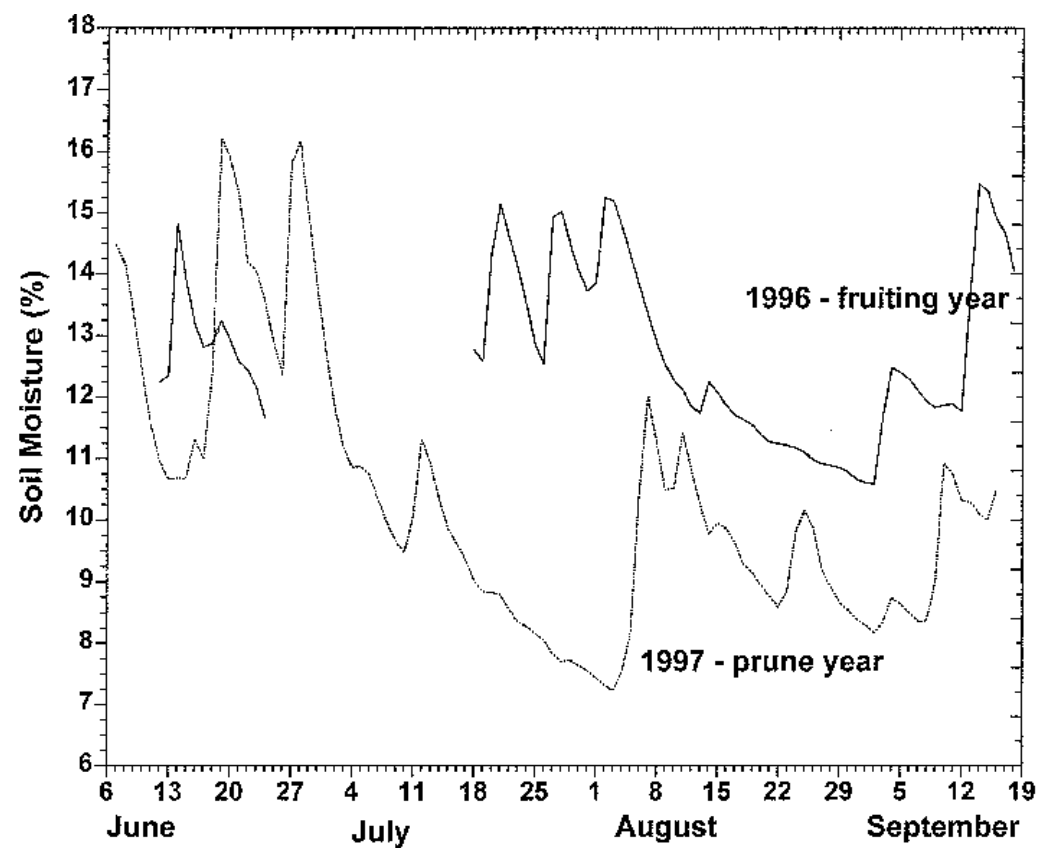

Fig. 3. Average daily volumetric soil moisture content for the top $15 \mathrm{~cm}$ of the soil profile under blueberry plants for the fruiting (1996) and prune (1997) years. Data not available between 24 June and 18 July 1996. 


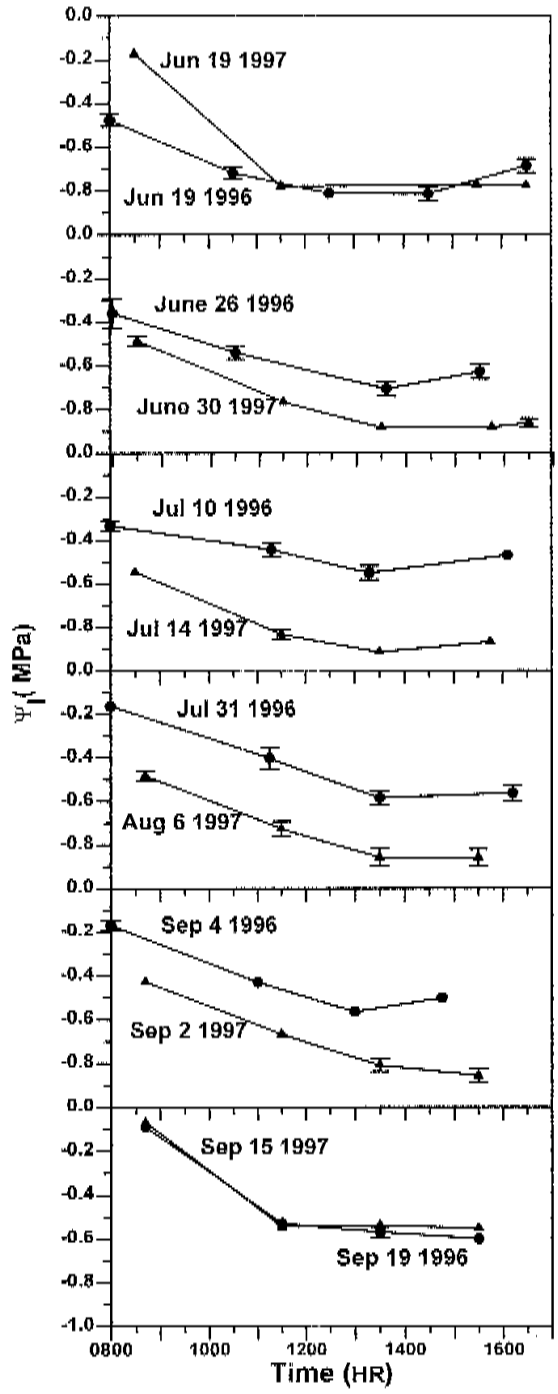

Fig. 4. Diurnal variation in leaf water potential $\left(2_{1}\right)$ of lowbush blueberry in the fruiting (1996) and prune (1997) years. Each point is the mean of 15 measurements (five each for 'Augusta', 'Brunswick', and 'Chignecto'). Bars as for Fig. 2.

from their seasonal maxima. The late season decline in $\mathrm{g}_{1}$ coincided with low $\mathrm{A}_{\mathrm{CO} 2}$ in fruiting year plants suggesting that lowered $\mathrm{g}_{\mathrm{l}}$ contributes to a reduced assimilative capacity at this time of year. There were few differences between fruiting-year $\mathrm{g}_{\mathrm{l}}$ in 'Chignecto' and 'Brunswick', but $\mathrm{g}_{1}$ was often higher in 'Augusta'. Through most of the year these differences were not reflected in higher $\mathrm{A}_{\mathrm{CO} 2}$, except in September when 'Augusta' showed a more gradual seasonal decline in $\mathrm{A}_{\mathrm{CO} 2}$.

In the prune year, diurnal changes in $g_{1}$ in June were similar to those of the fruit year although values were generally higher for each clone than those for fruiting-year plants (Fig. 5 ). This was surprising in view of the relatively large year-to-year differences in soil and plant water status (Figs. 3 and 4). Higher $\mathrm{g}_{1}$ coincided with higher prune year $\mathrm{A}_{\mathrm{CO} 2}$ early in the season. Similarly, in September, $\mathrm{g}_{1}$ values were often twice as high in the prune year as in the fruiting year over a similar VPD range. In mid-July (14 July), when $\mathrm{A}_{\mathrm{CO} 2}$ in

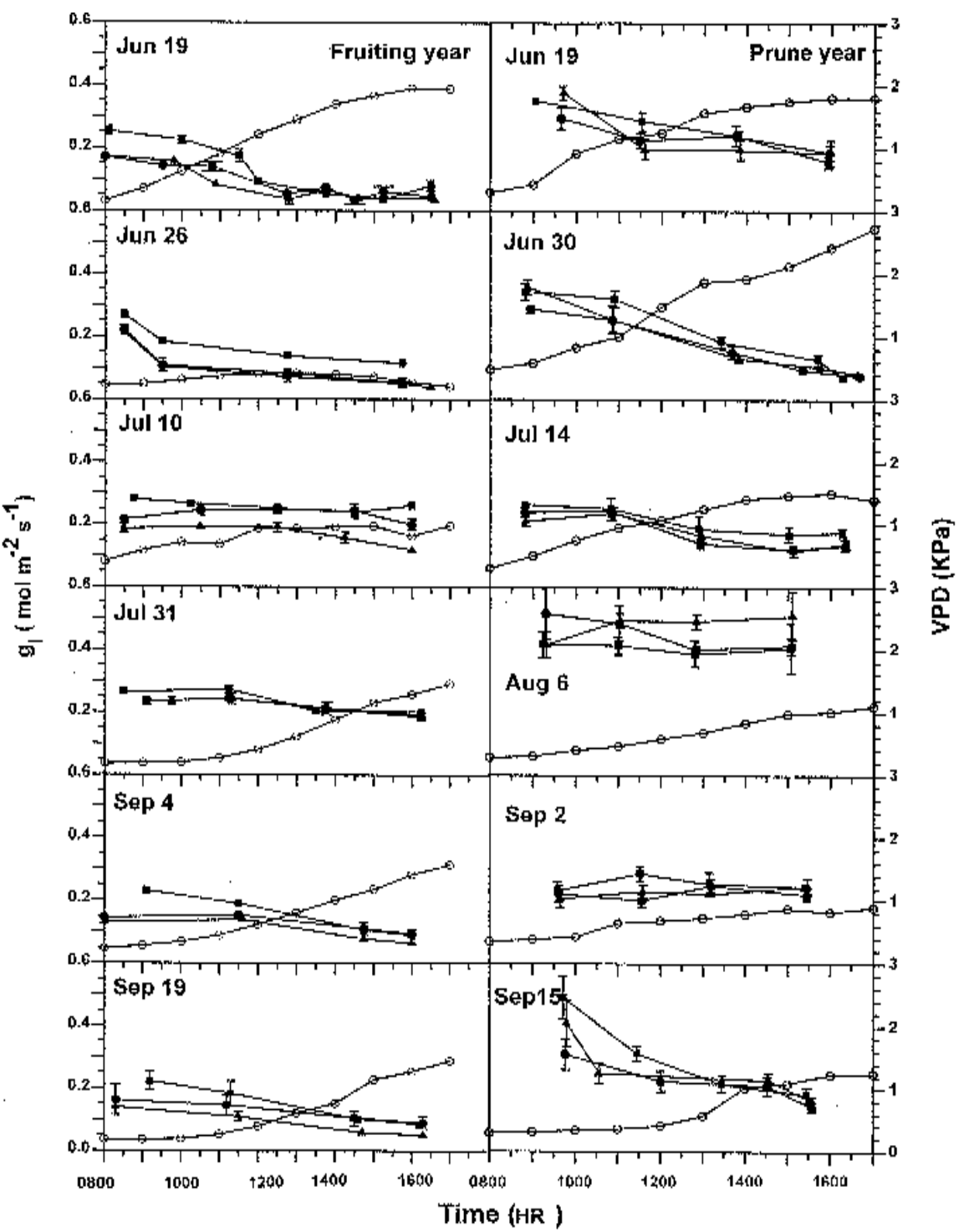

Fig. 5. Diurnal variation in stomatal conductance $\left(\mathrm{g}_{\mathrm{l}}\right)$ and vapor pressure deficit (VPD) for 'Augusta', 'Brunswick', and 'Chignecto' lowbush blueberry in the fruiting year (1996) and in the prune year (1997). Each point is the mean of five measurements on individual plants. Symbols and bars as for Fig. 2. VPD is represented by open symbols.

each clone was similar to that in the fruiting year, $g_{1}$ was also similar. However, on 6 Aug., under relatively low VPD, soil moisture, and $\psi_{1}, g_{1}$ were higher than on any other occasion in the 2-year crop cycle. This also coincided with maximal $\mathrm{A}_{\mathrm{CO} 2}$ in the prune year. Stomata are sensitive to light, temperature, atmospheric humidity, internal and external $\mathrm{CO}_{2}$ concentrations, and plant water status. There is a tendency for stomata to close as $\psi_{1}$ declines (Jarvis 1980), but in some species even moderate water deficits have no direct effect on $g_{1}$ until a critical level is reached (Ehlig and Gardner, 1964), whereas in others, notably apple (Malus $\times$ domestica Borkh.), $\psi_{1}$ is closely controlled by changes in $\mathrm{g}_{1}$ over a range of soil water contents (Jones et al., 1983). Our data, which actually show higher $\mathrm{g}_{1}$ under lower soil water contents and $\psi_{1}$ (in the prune year), suggest a weaker linkage between $\psi_{1}$ and $g_{1}$ in lowbush blueberry, although further work under controlled conditions is necessary for confirmation.
The factors responsible for observed withinand between-season differences in $\mathrm{g}_{1}$ are not clear from the present results, and it may be that $g_{1}$ is just one of several factors that influence seasonal $\mathrm{C}$-assimilative capacity in lowbush blueberries. Thus, higher $\mathrm{A}_{\mathrm{CO} 2}$ during June in the prune year compared with the fruiting year may be partly explained by higher $\mathrm{g}_{1}$ and hence a reduced stomatal limitation. In the prune year, however, $\mathrm{g}_{1}$ values were as high throughout the day on 19 June (when $\mathrm{A}_{\mathrm{CO} 2}$ was between $50 \%$ and $70 \%$ of seasonal maxima) as on 14 July when rates were maximal. In many cases, leaves reach their maximum photosynthetic potential at $80 \%$ of full leaf expansion (Besford et al., 1985; Roper and Kennedy, 1986), but changes in internal resistances to $\mathrm{CO}_{2}$ transfer, chloroplast structure, and relationships between photosynthesis and respiration change progressively through development (Šesták et al., 1985) and can lead to further alteration in photosynthetic potential. In lowbush blueberry, early formed leaves are 
apparently not fully photosynthetically competent, so that plant $\mathrm{C}$-assimilative capacity may not peak until mid-season.

Forsyth and Hall (1965) have reported significant differences in photosynthetic capacity between plants of different clonal origin. Our data do not indicate major differences between three other clones, but we cannot extrapolate from this small sample size to understand the range of photosynthetic variation in a diverse seedling population. We have barely begun to uncover the complex interactions between environment, genotype, $\mathrm{C}$-acquisition, and distribution patterns that underpin growth and development in all woody perennial species. The unique 2-year management system employed in commercial lowbush blueberry production provides an opportunity to investigate many aspects of $\mathrm{C}$-cycling and growth in a plant forced into a biennial cropping cycle. The results of the present study provide a baseline of information from which we may begin to investigate these more complex interactions.

\section{Literature Cited}

Aalders, L.E., I.V. Hall, and L.P. Jackson. 1977 'Brunswick' lowbush blueberry. Can. J. Plant Sci. 57:301.

Aalders, L.E., A.A. Ismail, I.V. Hall, and P.R. Hepler. 1975. 'Augusta' lowbush blueberry. Can. J.Plant Sci. 55:1079.

Besford, R.T., A.C. Withers, and L.J. Ludwig. 1985. Ribulose bisphosphate carboxylase activity and photosynthesis during leaf development in the tomato. J. Expt. Bot. 171:1530-1541.

Cann, D.B., J.D. Hilchey, and G.R. Smith. 1954. Soil survey of Hants County Nova Scotia. Expt. Farm Serv., Can. Dept. Agr. Rpt. No. 5.

Chapman, D.F., M.J. Robson, and R.W. Snaydon. 1991. Quantitative carbon distribution in clonal plants of white clover(Trifolium repens): Sourcesink relationships during undisturbed growth. J. Agr. Sci. 116:229-238.

Dyer, M.I., M.A. Acra, G.M. Wang, D.C. Coleman, D.W. Freckman, S.J. McNaughton, and B.R. Strain. 1991. Source-sink carbon relations in two Panicum coloratum ecotypes in response to herbivory. Ecology 72:1472-1483.
Ehlig, C.F. and W.R. Gardner. 1964. Relationship between transpiration and the internal water relations of plants. Agron. J. 56:127-130.

Fernandez, G.E. and M.P. Pritts. 1994. Growth, carbon acquisition, and source-sink relationships in 'Titan' red raspberry. J. Amer. Soc. Hort. Sci. 119:1163-1168.

Forsyth, F.R. and I.V. Hall. 1965. Effect of leaf maturity, temperature, carbon dioxide concentration, and light intensity on rate of photosynthesis in clonal lines of the lowbush blueberry, Vaccinium angustifolium Ait., under laboratory conditions. Can. J. Plant Sci. 43:893-900.

Gucci, R., P.D. Petracek, and J.A. Flore. 1991(a). The effect of fruit harvest on photosynthetic rate, starch content and chloroplast ultrastructure in leaves of Prunus avium L. Adv. Hort. Sci. 5:19-22.

Gucci, R., C. Xiloyannis, and J.A. Flore. 1991(b). Gas exchange parameters, water relations and carbohydrate partitioning in leaves of fieldgrown Prunus domestica following fruit removal. Physiol. Plant. 83:497-505.

Hall, I.V. 1955. Floristic changes following the cutting and burning of a woodlot for blueberry production. Can. J. Agr. Sci. 35:143-152.

Hall, I.V. 1958. Some effects of light on native lowbush blueberry. Proc. Amer. J. Hort. Sci. 72:216-218.

Hall, I.V., L.E. Aalders, and L.P. Jackson. 1977. 'Chignecto' lowbush blueberry. Can. J. Plant Sci. 57:1217-1218.

Hall, I.V. and R.A. Ludwig. 1961. The effects of photoperiod, temperature and light intensity on the growth of the lowbush blueberry (Vaccinium angustifolium Ait.). Can. J. Bot. 39:1733-1739.

Ismail, A.A. and E.J. Hanson. 1982. Interaction of method and date of pruning on growth and productivity of the lowbush blueberry. Can. J. Plant Sci. 62:677-682.

Jarvis, P.G. 1980. Stomatal response to water stress in conifers. p. 105-112. In: N.C. Turner and P.J. Kramer (eds.). Adaptation of plants to water and high temperature stress. Wiley, New York.

Jones, H.G., M.T. Luton, K.H. Higgs, and P.J.C. Hamer. 1983. Experimental control of water status in an apple orchard. J. Hort. Sci. 58:301316.

Kender, W.J. and D.A. Abdalla. 1966. Rhizomebud activity as it affects the propagation of lowbush blueberries by rhizome cuttings. Maine Agr. Expt. Sta. Misc. Rpt. 118:115-116.

Kender, W.J. and F.P. Eggert. 1966. Several soil management practices influencing the growth and rhizome development of the lowbush blueberry. Can. J. Plant Sci. 46:141-149.

Mandre, O., M. Rieger, S. Myers, R. Seversen, and J-L. Regnard. 1995. Interaction of root confinement and fruiting in peach. J. Amer. Soc. Hort. Sci. 120:228-234.

McDermitt, D.K. 1990. Sources of error in the estimation of stomatal conductance and transpiration from porometer data. HortScience 25:1538-1548.

Moon, J.W., J.A. Flore, and J.F. Hancock, Jr. 1987. A comparison of carbon and water vapor gas exchange characteristics between a diploid and highbush blueberry. J. Amer. Soc. Hort. Sci. 112:134-138.

Percival, D.C., J.T.A. Proctor, and M.J. Tsujita. 1996. Whole-plant net $\mathrm{CO}_{2}$ exchange of raspberry as influenced by air and root-zone temperature, $\mathrm{CO}_{2}$ concentration irradiation and humidity. J. Amer. Soc. Hort. Sci. 12:838-845.

Roper, T.R. and R.A. Kennedy. 1986. Photosynthetic characteristics during leaf development in 'Bing' sweet cherry. J. Amer. Soc. Hort. Sci. 111:938-941.

Sanderson, K.R. and J.A. Cutcliffe. 1991. Effect of sawdust mulch on yields of select clones of lowbush blueberry. Can. J. Plant Sci. 71:12631266.

Šesták, Z., I. Ticha, J. Catsky, J. Solarova, J. Pospisilova, and D. Hodanova. 1985. Integration of photosynthetic characteristics during leaf development, p. 263-286. In: Z. Šsták (ed.). Photosynthesis during leaf development. Dr. W. Junk Dordrecht, The Netherlands.

Teramura, A.H., F.S. Davies, and D.W. Buchanan. 1979. Comparative photosynthesis and transpiration in excised shoots of rabbiteye blueberry. HortScience 14:723-724.

Topp, G.C., J.L. Davis, and A.P. Annan. 1980. Electromagnetic determination of soil water content: Measurements in coaxial transmission lines. Water Resources Res. 16:574-582.

Trevett, M.F. 1956. Observations on the decline and rehabilitation of lowbush blueberry fields. Maine Agr. Expt. Sta. Misc. Pub. 616.

Vander Kloet, S.P. 1978. Systematics, distribution and nomenclature of the polymorphic Vaccinium angustifolium. Rhodora 80:358-376.

von Caemmerer, S. and G.C. Farquhar. 1981. Some relationships between the biochemistry of photosynthesis and the gas exchange of leaves. Planta 153:376-387. 